\title{
Our experience of sling operative correction of stress incontinent in women of Uzbekistan
}

\begin{abstract}
Summary
Stress urinary incontinence (SUI) occurs in $38-45 \%$ of women and with increasing age reaches $60 \%$. In recent years, synthetic materials have been used for surgical correction.

Purpose: Is to conduct a comparative evaluation of the effectiveness of urethropexy with prolene tape with anterior and posterior colpoperineolevatoroplasty in the correction of stress urinary incontinence.

Materials and methods: The results of plastic surgery with a free synthetic loop made of
Prolene - TVT-O for stress urinary incontinence in 54 patients are presented. The comparison
group consisted of 30 patients who underwent typical front and rear colpoperineorrhaphy.

Results: Normal urination function was restored 1 day after surgery. Blood loss, the course of the postoperative period, and the length of hospital stay were almost identical in both groups. There were no complications for 5 years $(100 \%)$ in the main group.
\end{abstract}

Conclusion: Sling surgical correction is an effective and reliable method of treating stress incontinence in women.

Keywords: stress urinary incontinence, women, sling surgical correction

\author{
Volume II Issue 4 - 2020
Gafurov JM,' Djabbarova YuK,' Ruzieva NKh'
'Republican Perinatal center of the Ministry of Health care Tashkent, Uzbekistan
${ }^{2}$ Tashkent pediatric medical institute of the Ministry of Health care, Tashkent, Uzbekistan

\begin{abstract}
Correspondence: Prof. Djabbarova Yulduz Kasimovna, DSc Republican perinatal center of the Ministry of Health, Tashkent, Republic of Uzbekistan, I00140 T Tashkent D.Abidova St. 223,
\end{abstract} Uzbekistan, Tel +998946996402, Email ulduzjab@mail.ru

Received: July 13, 2020 | Published: July 29, 2020

\section{Introduction}

Stress urinary incontinence in women is one of the most common and difficult problems in modern urology and gynecology. According to European and American scientists, about $38 \%-45 \%$ of the female population aged 35-60 years report symptoms of involuntary urine discharge. ${ }^{1-5}$ SUI in Uzbek women occurs in $30 \%$ of women. ${ }^{6}$

There are more than 200 ways to correct urinary incontinence. The incidence of complications and relapses after surgical treatment ranges from $6 \%$ to $51 \%$. Recently began to use a sling interference with the use of synthetic materials. The main advantages of these operations are their low invasiveness and atraumatic. ${ }^{7-12}$ Pelvic organ prolapse (POP) and urinary incontinence stress (SUI) in women - occur in 50$75 \%$ of women after childbirth, the disease is of a combined nature in $70-80 \%$ of stage III-IV cystocele cases it is combined with urinary incontinence stress. ${ }^{13}$ In the review of ${ }^{4}$ there are indications that prolapse of the genitalia organs usually coexist with SUI in $20 \%$. In every second woman over 45 years of age, involuntary urine release is observed in combination with genital prolapse. ${ }^{7}$ Pelvic prolapse and stress incontinence reduce the quality of life of patients by $64 \% .{ }^{14}$

The purpose of this study is to compare the effectiveness of urethropexy with prolene tape with anterior and posterior colpoperineolevatoroplasty in the correction of stress urinary incontinence.

\section{Materials and research methods}

The results of plastic surgery with a free synthetic loop made of Prolene - TVT-O (Tension-free Vaginal Tape) for stress urinary incontinence over the past 5 years in the gynecological department of the Republican perinatal center in 54 patients are presented. The average age of patients was 49.5 years. These were mainly residents of the city-79,\% and the rest-housewives- $57.4 \%$, who had 3 births and more-59.3\%. All patients were examined, which included: collecting a history, filling out a diary of urination for 7 days, gynecological examination in mirrors - checking the symptom of a cough push, diagnosis of prolapse of the genitals, ultrasound of the kidneys and bladder (elimination of organic pathology, volume of residual urine), small pelvic ultrasound by vaginal sensor at rest and when strained, general blood test, biochemical blood test, coagulogram, general urine analysis, urine sowing with microbial number, bacteriological examination of cervical mucus, bacterioscopic, bacteriological methods for assessing the condition of vaginal microflora. RW, HIV/ AIDS, hepatitis B, C. ECG, echocardiogram, lower extremity vein dopplerometry, and therapist consultation were performed. In all patients there was a lowering of the anterior and posterior walls of the vagina of 2-3 degrees, failure of the pelvic floor muscles, and stress incontinence of the urine. A typical operation of anterior and posterior colperineoleuroplasty and TVT-O were performed. The operation was based on the TVT-O technician in the modification of J. De Laval. ${ }^{15}$ The operation was performed using specially designed tools and a device with two needles connected to a $45 \mathrm{~cm}$-long and $1.1 \mathrm{~cm}$ wide Proline tape enclosed in a plastic case. By conducting needles paraurethral, paravesical through the pelvic diaphragm and the fascia of the rectus abdominis muscle out through the skin above the womb, and cut off the tape recorded in the area of the mid urethra with no tension. The operation was performed under cerebrospinal anesthesia. The comparison group consisted of 30 patients who underwent typical front and rear colpoperineorrhaphy. It's about age, place of residence. the social situation and parity of births did not reliably differ from the main group.

\section{Results}

It was established that the average age of patients with stress incontinence was 49 years (from 34 to 80years). Most women with SUI were aged $40-49$ years $(53,7 \%), 50-59$ years - 20,4\% and at the age of $60-80$ years-18,5\% (Table 1). $16(29,6 \%)$ patients were postmenopausal. Dispensary observation averaged 7 years (2 years - 15years). Residents of the city dominated $-43(79,6 \%)$, $11(20,4 \%)$ women were from the village (Table 1). Professional 
employment: employees were $33,3 \%$ (18), pensioners-9,3\% (5), the rest - housewives 57,4\% (31) (Table 1). Births through natural birth pathways were in all women (100\%). The number of births in the history (Table 1): 2-in 35,2\% (19) women, 1 birth-in 5,6\% (3) women, 3 births or more-59,3\% (32) women. 11 (20,4\%) women had a history of gynecological surgery (Table 2): hysterectomy- $5,6 \%$ (3), salpingectomy- $-5,6 \%$ (3), vaginal plastics $-3,7 \%$ (2), cervical pathology- $5,6 \%$ (3). During the investigation, the following somatic diseases were most often identified (Table 2): lower extremity varicose disease $-77,8 \%$ (42), hypertensive disease-22,2\% (12), heart disease-14,8\% (8), gastrointestinal tract disease- $13 \%(7)$, obesity 2-3 degree-y 14,8\% (8). 40 (74,1\%) women, the occurrence of urinary incontinence was associated with traumatic, complicated labor ruptures, childbirth with a large fetus $14(25.9 \%), 11(20,4 \%)$ women with gynaecological operations, $12(22,2 \%)$-with the onset of menopause, $5(9,3 \%)$ - with severe physical exertion. During the operation, no complications were noted. The total duration of the operation was 1 , 8hours, of which TVT-O operations ranged from 20 to 25 minutes. Blood loss $(75-100 \mathrm{ml})$, the course of the postoperative period, and the length of hospital stay $(3,1$ day) were almost identical in both groups.In all patients, the Foley catheters was removed 10 hours after surgery. In 52 patients $(96,3 \%)$, after removal of the catheters, self-urination was restored. In 2 cases $(3,7 \%)$ there was a delay in urination of 2 days. At ultrasound, residual urine volume after surgery was not detected in all patients. The patients felt comfortable after the sling operation, their ability to work was restored, and their quality of life improved. No complications or relapses were observed for 5 years $(100 \%)$.In the comparison group after vaginal plastic, SUI simtomas occurred after 2 years in 3 and after 3 years in 2 patients, which was $16.7 \%$.

Table I Some social indicators operated women with SUI

\begin{tabular}{|c|c|c|c|c|}
\hline \multirow{2}{*}{$\begin{array}{l}\text { Indicators } \\
\text { Age, years }\end{array}$} & \multicolumn{2}{|c|}{$\begin{array}{l}\text { Main group, } n=54 \\
\text { Plastika of a vagina+TVT-O }\end{array}$} & \multicolumn{2}{|c|}{$\begin{array}{l}\text { Comparison group, } n=30 \\
\text { Plastika of a vagina }\end{array}$} \\
\hline & abs & $\%$ & abs & $\%$ \\
\hline $30-39$ & 4 & $7,4 \pm 3,5$ & 2 & $6,7 \pm 4,6$ \\
\hline $40-49$ & 29 & $53,7 \pm 6,8$ & 14 & $46,7 \pm 9,1$ \\
\hline $50-59$ & 11 & $20,4 \pm \mid 2,1$ & 7 & $23,3 \pm 7,7$ \\
\hline 60 and older & 10 & $18,5 \pm 5,3$ & 7 & $23,3 \pm 7,7$ \\
\hline \multicolumn{5}{|l|}{ Place of residence } \\
\hline the city & 43 & $70,6 \pm 6,2$ & 23 & $76,7 \pm 7,7$ \\
\hline the village & II & $20,4 \pm \mid 2, I$ & 7 & $23,3 \pm 7,7$ \\
\hline \multicolumn{5}{|c|}{ Professional employment } \\
\hline the rest - housewives & 31 & $57,4 \pm 6,7$ & 14 & $46,7 \pm 9,1$ \\
\hline employees & 18 & $33,3 \pm 6,4$ & 11 & $36,7 \pm 8,8$ \\
\hline pensioners & 5 & $9,3 \pm 3,9$ & 5 & $16,7 \pm 6,9$ \\
\hline \multicolumn{5}{|c|}{ The number of births } \\
\hline I & 3 & $5,6 \pm 3,2$ & 1 & $3,3 \pm 3,1$ \\
\hline 2 & 19 & $35,2 \pm 6,5$ & 9 & $30,0 \pm 8,3$ \\
\hline $3-10$ & 32 & $59,3 \pm 6,7$ & 20 & $66,7 \pm 8,6$ \\
\hline
\end{tabular}

Note: the difference in these groups is unreliable-p $>0,05$

Table 2 Somatic pathology and gynecological surgery in women with SUI

\begin{tabular}{lllll}
\hline \multirow{2}{*}{ Diseases } & \multicolumn{2}{l}{$\begin{array}{l}\text { Main group, } \mathbf{n = 5 4} \\
\text { Plastika of a vagina+TVT-O }\end{array}$} & \multicolumn{2}{l}{$\begin{array}{l}\text { Comparison group, } \mathbf{n = 3 0} \\
\text { Plastika of a vagina }\end{array}$} \\
\cline { 2 - 6 } & abs & $\%$ & abs & $\%$ \\
\hline Lower extremity varicose disease & 42 & $77,8 \pm 5,6$ & 21 & $70,0 \pm 8,3$ \\
Hypertensive disease & 12 & $22,2 \pm 5,6$ & 10 & $33,3 \pm 8,6$ \\
Heart disease & 8 & $14,8 \pm 4,8$ & 5 & $16,7 \pm 6,9$ \\
Thyroid disease & 7 & $13,0 \pm 4,6$ & 7 & $23,3 \pm 7,7$ \\
Obesity 2-3 degree & 8 & $14,8 \pm 4,8$ & 7 & $23,3 \pm 7,7$ \\
Gastrointestinal tract disease & 3 & $5,6 \pm 3,2$ & 4 & $13,3 \pm 6,1$ \\
Diabetes mellitus & 2 & $3,7 \pm 2,4$ & 2 & $6,7 \pm 4,6$ \\
Gynaecological operations: & 11 & $20,4 \pm 5,4$ & 8 & $26,7 \pm 8,1$ \\
Gisteretomiya & 3 & $5,6 \pm 3,2$ & 1 & $3,3 \pm 3,1$ \\
Salpigektomiya & 3 & $5,6 \pm 3,2$ & 1 & $3,3 \pm 3,1$ \\
Plastika of a vagina & 2 & $3,7 \pm 2,4$ & 2 & $6,7 \pm 4,6$ \\
Cervical pathology & 3 & $5,6 \pm 3,2$ & 4 & $13,3 \pm 6,1$ \\
\hline
\end{tabular}

Note: the difference in these groups is unreliable-p $>0.05$ 


\section{Discussion}

Thus, we made sure that sling surgery in patients with stress urinary incontinence using mesh implants (TVT-O) is highly effective, safe, with a short hospital stay and can be successfully used as the first line of surgical treatment for SUI. Currently, the most rational is one of the modified strategies-combined surgery with simultaneous POP surgery and urinary incontinence surgery. A recent meta-analysis confirmed a reduced risk of postoperative SUI in combined POP and UI surgery, but also showed a detrimental effect on women treated with combination surgery ${ }^{16}$ The results of our study confirmed L. Lin's data that TVT is the best choice in SUI management for women with previous POP surgery ${ }^{2}$ and may reduce postoperative development of stress urinary incontinence (SUI). ${ }^{17-19}$

However, the rather high cost of the synthetic tape itself with its tools significantly reduces the possibility of widespread use of this method among patients in Uzbekistan. This leads to the search for and development of new more economical methods of sling correction of SUI in women.

\section{Conclusion}

Remote results of operations were followed by us within 5years and have been evaluated as good. Sling surgical correction is an effective and reliable method of treating stress incontinence in women. Combined genitalia prolapse correction and SUI is an efficient and cost-effective approach.

\section{Acknowledgments}

None.

\section{Funding}

The authors of this article confirm the lack of financial or any other support that needs to be reported.

\section{Conflicts of interest}

The authors confirm the absence of any other conflict of interest that needs to be reported.

\section{References}

1. Bachkangi P, Salman M. Complications of mid-urethral tape insertion. Journal of Clinical Gynecology and Obstetrics. 2019;8(2):44-47.

2. Lin L, Huang MC, Su TH, ettt al. Comparison between tensionfree vaginal tape and transobturator tape in treating stress urinary incontinence after vaginal mesh surgery. Taiwan J Obstet Gynecol. 2018;57:528-531

3. Musin II, Yashchuk AG, Dautova LA, et al. Methods of surgica correction of the urinary incontinence in women of reproductive age. Medicinskij vestnik Bashkortostana. 2013;8(4):90-94.

4. Wang PH. Mid-urethral sling in the management of women with stress urinary incontinence after pelvic organ prolapse treatment. Taiwan $J$ ObstetGynecol. 2018;57(6):777-778.
5. Wein AJ. et al. Updated systematic review and meta-analysis of the comparative data on colposuspensions, pubovaginal slings, and midurethral tapes in the surgical treatment of female stress urinary incontinence. J Urol. 2019;201(1):36-37.

6. Abdurizaev AA, Gaybullaev AA, Sarimov FS. Female urinary incontinence in Tashkent (Uzbekistan): prevalence and risk factors. Medicinskaja nauka. 2015:33-38.

7. Bakas P, Papadakis E, Karachalios C, et al. Long-term efficacy follow-up of tension-free vaginal tape obturator in patients with stress urinary incontinence with or without cystocele. Int J GynaecolObstet. 2018;143(3):339-343.

8. Bezhenar VF, Rusina EI, Tsuladze LK, et al. Prognostic and predisposing risk factors for perinatal pathology in women with various forms of hyperhomocysteinemia. Journal of obstetrics and female diseases. 2012;61(5):30-37.

9. Diallo S, Cour F, Josephson A, et al. Evaluating single-incision slings in female stress urinary incontinence: the usefulness of the CONSORT statement criteria. Urology. 2012;80(3):535-541.

10. Petri E, Ashok K. Comparison of late complications of retropubic and transobturator slings in stress urinary incontinence. Int Urogynecol J. 2012;23(3):321-325

11. Serati M, Ghezzi F, Cattoni E, et al. Tension-free vaginal tape for the treatment of urodynamic stress incontinence: efficacy and adverse effects at 10-year follow-up. Eur Urol. 2012;61(5):939-946.

12. Song PH, Yoo ES. Five-year outcomes of the transection of synthetic suburethral sling tape for treating obstructive voiding symptoms after transobturator sling surgery. Urology. 2012;80(3):551-555.

13. Mironov VN. Optimization of diagnosis and surgical treatment of combined forms of pelvic prolapse and stress of urinary incontinence in women. Sankt- Petersburg; 2015. 37 p

14. Lyulko AA. Comprehensive evaluation of diagnostic criteria in women with cystocele and stress urinary incontinence. Zdorovye zhenshchiny. 2017;123(7):107-110.

15. De Laval J. Novel surgical technique for the treatment of female stress urinary incontinence: transobturator vaginal tape inside-out. Eur Urol. 2003;44(6):724-730

16. van der Ploeg JM, van der Steen A, Zwolsman S, et al. Prolapse surgery with or without incontinence procedure: a systematic review and metaanalysis. BJOG. 2018;125:289-297.

17. Burkhard FC, Lucas MG, Berghmans LC, et al. Recommendations of European asociation of urologists (EAU on urinary incontinence. 2016.

18. Baessler K, Christmann-Schmid C, Maher C et al. Surgery for women with pelvic organ prolapse with or without stress urinary incontinence. Cochrane Database Syst Rev. 2018;8(8):CD013108

19. Chaudhari VV, Patel MK, Douek M, et al. MR Imaging and US of Female Urethral and Periurethral Disease. RSNA. 2010:86-90. 